\title{
THE ILLEGALITY DEFENCE AND COMPANY LAW
}

Ernest Lim*

\section{INTRODUCTION}

The 2009 report by the Law Commission - The Illegality Defence: A Consultative Report ${ }^{1}$ (the “2009 Report”) and its final 2010 report - The Illegality Defence 2 (the "2010 Report”) are products of an extensive review of the illegality defence as applied to the law of contract, tort, unjust enrichment and trusts. The 2010 Report defines the illegality defence as arising "when the defendant in a private law action argues that the claimant should not be entitled to their normal rights or remedies because they have been involved in illegal conduct which is linked to the claim." ${ }^{3}$ One of the key recommendations in the 2009 Report (which was affirmed in the 2010 Report) is that "the illegality defence should be allowed where its application can be firmly justified by the policies that underlie its existence. These include: "(a) furthering the purpose of the rule which the illegal conduct has infringed; (b) consistency; (c) that the claimant should not profit from his or her own wrong; (d) deterrence; and (e) maintaining the integrity of the legal system." ${ }^{4}$

\footnotetext{
${ }^{1 *}$ Faculty of Law, University of Hong Kong. I would like to thank the anonymous reviewer, the editor and Peter Chau for very helpful comments. All errors are mine alone. Email: elimwk@hku.hk

The Law Commission (England and Wales), The Illegality Defence: A Consultative Report, Consultation Paper No 189 (2009).

${ }^{2}$ The Law Commission (England and Wales), The Illegality Defence, Law Com No. 320 (2010).

${ }^{3}$ The Law Commission (England and Wales), The Illegality Defence, Law Com No. 320 (2010) at para 1.2, vi.

${ }^{4}$ The Law Commission (England and Wales), The Illegality Defence: A Consultative Report, Consultation Paper No 189 (2009) at para 8.1, p 147.
} 
The 2010 Report applauded the way the illegality defence was handled by the courts in recent cases involving contract and tort. ${ }^{5}$ The 2010 Report cited with approval, among other cases, Gray $v$ Thames Trains $^{6}$ in which the court considered the illegality defence in tort law and the House of Lords case of Stone \& Rolls v Moore Stephens('Moore Stephens") ${ }^{7}$ which concerned the illegality defence in both contract and tort. This is because those cases explicitly articulated the policy rationale (ie consistency) that underlie the illegality defence instead of mechanically applying the reliance principle. . The Law Commission would have been equally pleased with the recent Court of Appeal decision in Safeway Stores v Twigger ("Safeway") ${ }^{8}$ as the court examined and applied the consistency rationale underlying the illegality defence instead of slavishly invoking the reliance principle. The reliance principle states that the claimant will be able to enforce his or her usual rights despite the involvement of illegality at some point in the transaction, provided that he or she does not have to "rely" on that illegality to prove the claim. ${ }^{9}$ A key objection raised by the Law Commission is that the reliance principle ignores the crucial question whether to allow the claimant to succeed would tend to promote or to defeat the purpose of the rule of law which makes the transaction illegal.

\footnotetext{
${ }^{5}$ The Law Commission (England and Wales), The Illegality Defence, Law Com No. 320 (2010) at para 3.10-3.33, p 43-46.

${ }^{6}[2009] 1 \mathrm{AC} 1339$.

${ }^{7}[2009] 1 \mathrm{AC} 1391$.

${ }^{8}$ [2010] EWCA Civ 1472. This decision was handed down after the 2010 Report was published.

${ }^{9}$ The Law Commission (England and Wales), The Illegality Defence: A Consultative Report, Consultation Paper No 189 (2009) at para 3.46. See also Standard Chartered Bank v Pakistan National Shipping Corporation [2000] 1 Lloyd's Rep 218 at 232; Archbolds (Freightage) Ltd v S Spanglett Ltd [1961] 1 QB 374 at 388; Colen v Cebrian (UK) Limited [2003] EWCA Civ 1676, [2004] ICR 568 at 23.
} 
But a fundamental and recurring problem-which has been neglected in the scholarly literature to date ${ }^{10}$ - with both the 2009 and 2010 Reports and the recent cases involving companies as claimants which the 2010 Report endorsed, Moore Stephens, and especially the subsequent case of Safeway, is this. They fail to take into account the special doctrinal and policy features in company law when they examined the policy rationales underlying the illegality defence. This failure has led to a distorted application of the illegality defence in cases involving companies seeking to enforce duties owed to them by directors or third parties.

This article fills this salient gap in the scholarly literature by advancing the argument that in cases involving the claimant as a company (such as those in Safeway and Moore Stephens) as opposed to an individual, although the causes of action in the former cases are similar to the latter cases insofar as both are founded on contract and/or tort ${ }^{11}$, the distinctive considerations pertaining to company law meant that the policy rationales underlying the illegality defence that are applicable to cases involving individuals as claimants cannot be so easily transposed to cases involving the company as a claimant without careful attention to those considerations. Those considerations include but are not limited to doctrinal features such as separate legal personality and corporate attribution, corporate objectives, the Companies Act 2006, and policy concerns such as, for example, whether the rule which the illegal conduct has infringed is intended to

\footnotetext{
${ }^{10}$ D. Sheehan, "The Law Commission on Illegality: The End (At Last) of the Saga" (2010) L.M.C.L.Q. 543; P.S. Davies, "The Illegality Defence: Turning Back the Clock" (2010) Conv 282; P.S. Davies, "The Illegality Defence and Public Policy" (2009) L.Q.R. 556; P. Watts, "Stone \& Rolls Ltd (in Liquidation) v Moore Stephens (A Firm): Audit Contracts and Turpitude" (2010) 126 L.Q.R. 14; D. Halpern, "Stone \& Rolls Ltd. V Moore Stephens: An Unnecessary Tangle (2010) 73 M.L.R. 497; P. S. Davies, “Auditors' Liability: No Need to Detect Fraud" (2009) 68 C.L.J. 505; M. Naniwadekar, "Directing Minds and Agents: An Essay on Fraud and Attribution" (2010) J.B.L. 271; E. Ferran, "Corporate Attribution and the Directing Mind and Will" (2011) 127 L.Q.R. 239.

${ }^{11}$ For example, the company in Safeway sued the directors for breach of duties and employees for breach of employment contracts as well as for negligence, and the company in Moore Stephens sued the auditors for breach of duty of care in both contract and tort.
} 
deprive the company from asserting its common law and statutory ${ }^{12}$ remedies against directors for breach of duties. If the courts were to take into account these distinctive considerations pertaining to company law, they would be very cautious in allowing the defendant's illegality defence to succeed, as that defence might not be firmly justified by the policy-the consistency rationale-that underlie its existence.

Part I explains the consistency rationale as that was the primary rationale underlying the illegality defence deployed by the courts in Moore Stephens and Safeway in which the claimant was a company. The secondary rationale which was briefly stated in Moore Stephens is that the claimant should not profit from its wrongdoing ${ }^{13}$. And although one judge in Safeway said that denying the company's claim would achieve deterrent effect ${ }^{14}$, Longmore $L J$ who gave the leading judgment (and with whom Lloyd LJ agreed) deployed consistency as the sole policy rationale underlying the illegality defence in his judgment.

Part II explains the first of the three distinctive considerations pertaining to company law ${ }^{15}-$ corporate attribution and separate legal personality—which should be carefully borne in mind by the courts when defendants plead the illegality defence in order to strike-out claims brought by companies seeking to enforce duties owed to them by the defendants who are directors and officers as well as third parties. It will be argued that in applying the consistency rationale to cases involving companies as claimants, the court in Moore Stephens and Safeway failed to appreciate the doctrinal feature of corporate attribution; the acts of the delinquent director(s)

\footnotetext{
${ }^{12}$ Companies Act 2006, section 178.

${ }^{13}$ Stone \& Rolls v Moore Stephens [2009] 1 AC 1391 at para 120 (per Lord Scott dissenting).

${ }^{14}$ [2010] EWCA Civ 1472 at para 44 (per Pill LJ).

${ }^{15}$ It should be emphasized that these three considerations, although distinctive to company law, are not exhaustive or exclusive. There are other distinctive considerations relating to company law.
} 
were erroneously attributed to the claimant company in order to defeat an admitted breach of duty by them, a breach that had caused the company to incur liabilities that it would not otherwise have occurred. And in relation to separate legal personality, it will be argued that by treating the directors and employees (in the case of Safeway) and the sole director and shareholder (in the case of Moore Stephens) as though they were the company itself who were seeking to challenge the illegality defence, the court contravened the long established principle that although a company is an artificial entity and can only act through natural persons, it is to be treated as a legal personality separate and distinct from its directors and shareholders.

Part III explains the second distinctive consideration pertaining to company law -- corporate objectives. It will be argued that courts should take into account the enlightened shareholder model and stakeholder theory of corporate objective in determining whether the illegality defence should be allowed to defeat a company's claim. It will be argued that the failure to do so will lead to adverse consequences for the shareholders and the stakeholders (especially the creditors).

Part IV explains the final distinctive consideration, the Companies Act 2006. It will be argued that since the prevention of inconsistency between the different aspects of law is a central policy rationale underlying the illegality defence, courts should consider whether barring a company from recovering damages, which is a consequence of the sentence imposed upon it for its criminal or quasi criminal act, will render the law inconsistent, insofar as it does not sit well with several provisions in the Act which provide for civil remedies for a company when it is subject to sanctions as a result of its commission of certain criminal offences.

\section{I: THE CONSISTENCY RATIONALE}


The consistency rationale was deployed by the courts as a justification underlying the illegality defence in cases involving companies. Lord Philips in Moore Stephens cited the submission from the defendant's counsel, Jonathan Sumption $\mathrm{QC}^{16}$ (now Lord Sumption) that "the best policy rationale for the illegality defence is that suggested by McLachlin $\mathrm{J}$ in Hall v Hebert ${ }^{\prime \prime 17}$ :

“...to allow recovery in these cases would be to allow recovery for what is illegal. It would put the courts in the position of saying that the same conduct is both legal, in the sense of being capable of rectification by the court, and illegal. It would, in short, introduce an inconsistency in the law. It is particularly important in this context that we bear in mind that the law must aspire to be a unified institution, the parts of which - contract, tort, the criminal law - must be in essential harmony. For the courts to punish conduct with the one hand while rewarding it with the other, would be to 'create an intolerable fissure in the law's conceptually seamless web... We thus see that the concern, put at its most fundamental, is with the integrity of the legal system."18

Likewise, Lord Walker ${ }^{19}$ and Lord Mance ${ }^{20}$ in Moore Stephens also cited the policy rationale stated by McLachlin $\mathrm{J}$ in Hall v Hebert.

The facts in Moore Stephens can be briefly stated. Mr Stojevic, the sole director and sole beneficial shareholder used the company, S\&R, as a vehicle to carry out a letter of credit fraud

\footnotetext{
${ }^{16}$ Interestingly, Lord Sumption was also the lead counsel for the defendants in Safeway. Like Moore Stephens, the court in Safeway invoked the consistency rationale and ruled in favor of the defendant because of the illegality defence.

${ }^{17}$ (1993) 101 DLR (4th) 129 at 165.

${ }^{18}$ [2009] 1 AC 1391 at para 7 (emphasis added).

${ }^{19}$ [2009] 1 AC 1391 at para 128.

${ }^{20}$ [2009] 1 AC 1391 at para 226.
} 
against certain banks. S\&R and Mr Stojevic were successfully sued for deceit by one of the banks. S\&R alleged that the auditors breached their duty of care of care and skill by failing to detect the fraud and this prolonged the company's losses. The auditors accepted that they were in breach of their duty and conceded that but for their breach, the fraud would have been detected earlier. The liquidator sought to recover from the auditors the losses caused by the extension of the period of fraud. The auditors raised the illegality defence and argued that the company's claim should be struck out because the company had to rely on its own illegal conduct in order to sue the auditors. The majority held that the fraud of the directing mind and will, Mr Stojevic, was to be attributed to the company and since Mr Stojevic's fraud was the company's fraud, the company was barred from recovering compensation for the consequences of its own illegality.

In Safeway, the claimant company was liable to pay a hefty penalty (which could be more than $£ 16$ million) because it breached section 2(1) of the Competition Act which prohibited pricefixing. The claimant alleged that the defendants (comprising the directors and employees) breached their contract and/or fiduciary duties by participating in the prohibited price-fixing initiatives. The claimant sued the defendants by seeking an indemnity for the penalty. The defendants argued that the claimant's suit should be struck out on the basis of the illegality defence because the claimant was seeking to recover a benefit (the indemnity) from the unlawful act. The court struck out the company's claim. It was held that to allow the company under the civil law to recover from the defendants the penalty imposed on it by the criminal law would be inconsistent with the latter. Longmore LJ explained and applied the consistency rationale in the following terms: 
"The rationale of the maxim is the need for the criminal courts and the civil courts to speak with a consistent voice. It would be inconsistent for a claimant to be criminally and personally liable (or liable to pay penalties to a regulator such as the OFT) but for the same claimant to say to a civil court that he is not personally answerable for that conduct." ${ }^{21}$

\section{CORPORATE ATTRIBUTION AND SEPARATE LEGAL PERSONALITY}

\section{A. Corporate Attribution}

It is trite law that the legal identity of a company is separate from its directors and shareholders. A company, once legally incorporated, "must be treated like any other independent person with its rights and liabilities appropriate to itself." 22 Of course, a company being an artificial entity can only act through its agents. But, although the acts or state of mind of certain agents could be and are rightfully attributed to the company in order to make the company criminally, tortiously, contractually or statutorily liable in accordance with the language, purpose and policy of the rule in question (such as, for example, where the illegal price-fixing acts of the directors in Safeway were attributed to the company in order to make the company liable under the Competition Act 1998, or where the fraud perpetrated on the banks by the sole director and shareholder in Moore Stephens was ascribed to the company in order to hold the company liable for the tort of deceit to the banks), it does not follow that the acts of those agents should also be attributed to the company in order to defeat, on the basis of the illegality defence, the company's claim against its

\footnotetext{
${ }^{21}$ [2010] EWCA Civ 1472 at para 16.

${ }^{22}$ Salomon v Salomon \& Co Ltd [1897] AC 22 at 30 per Lord Halsbury LC.
} 
agents, or third parties, for breach of duties. ${ }^{23}$ Two examples suffice for now to illustrate this point. By allowing the defendants' illegality defence to succeed, the court in Safeway was in effect attributing to the company the acts of its directors and employees and in Moore Stephens, the acts of its sole director, in order to defeat an admitted breach of duty by them, a breach that had caused the company to incur liabilities that it would not otherwise have occurred.

In Safeway, the defendant directors and employees successfully pleaded the illegality defence to preclude the company's claim against them for breach of duty under contract and tort. The company did so in order to recover from the defendants the penalty imposed upon it as a result of breaching the Competition Act 1998. The breach was caused by the defendants' participation in the illegal price-fixing initiatives. The Court of Appeal held that the illegality defence barred the company from recovering the penalty from the very directors and employees whose conduct had caused the company to incur liability. This is because, according to Longmore LJ (with whom Lloyd LJ agreed), to allow the company's claim would create an inconsistency between the criminal law (under which the company was liable to pay the penalty) and civil law (under which the company was suing to recover the penalty). ${ }^{24}$

But it can be argued that there is no inconsistency in the law to allow the company's claim. Or at the very least, the different corporate attribution issue that arises from criminal law as compared to civil law has to be carefully considered when courts seek to justify the application of the illegality defence on the basis of avoiding inconsistency. Under the criminal law, the wrongful

\footnotetext{
${ }^{23}$ E. Ferran, "Corporate Attribution and the Directing Mind and Will" (2011) 127 L.Q.R. 239; E. Lim, "A Critique of Corporate Attribution: "Directing Mind and Will" and Corporate Objectives" J.B.L. (forthcoming). ${ }^{24}$ [2010] EWCA Civ 1472 at para 16.
} 
acts of the company's agents are rightfully attributed to the company in order to make the company liable for breaching the rule (for example, the statute) in question. Under the civil law, however, when the court strikes out a company's claim on the basis of the defendants' illegality defence, the court is in effect attributing the wrongful acts of the defendants to the company in order to defeat its claim against them for breach of duties that they owe to it. But such an attribution is unjustified. Under the criminal law, in order to make the company liable, certain acts of its agents have to be attributed to the company. But when a company sues the defendants under the civil law to recover from them a penalty imposed upon it which is caused by the defendants' illegality, the issue, unlike under the criminal law, is not which acts of which agents should count as the company's acts for the purpose of fixing liability on the company. On the contrary, the issue is whether the acts of its agents should be attributed to the company in order to defeat its claim against them for breach of duties. But the court in Safeway failed to justify such an attribution on the basis of precedent or policy.

In Moore Stephens, the House of Lords held three to two that the defendant auditors succeeded in invoking the illegality defence and thus the insolvent company, acting through its liquidator, was barred from suing them for breach of duty of care under contract and tort for failing to detect the fraud perpetuated against the banks by the company's sole director and shareholder. This was despite the auditors' admission that they were in breach: they conceded that but for their breach, the fraud would have been detected earlier and thus, the losses caused by the extension of the period of fraud could have been prevented. 
Although two of the three Law Lords in the majority mentioned the consistency rationale with approval, they paid lip service to it. It is submitted that there is no inconsistency between the criminal law and civil law as the company was not suing to recover for damages caused by a criminal sentence because there was no such sentence in the first place. ${ }^{25}$ On the contrary, the company was merely seeking to recover from the auditors the damages that were awarded, in a civil action, to the banks (which were its creditors) against the company and the delinquent director as result of the fraud perpetrated on the banks by that director.

It is submitted that the reasoning in Moore Stephens and Safeway is not firmly supported by precedent or policy. As Lord Mance in his dissent trenchantly concluded after a careful examination of In re Hampshire Land Company ${ }^{26}$, Belmont Finance v Williams Furniture ${ }^{27}$ and Attorney General's Reference (No 2 of 1982) ${ }^{28}$ the law “prevents a company being treated as party to a fraud committed by its officers "on" or "against" the company, at least in the context of claims by the company for redress for offences committed against the company." ${ }^{29}$ His Lordship held that in cases involving a company seeking recourse from persons who owe duties and have committed wrongs towards it, such situations "compel by their nature a separation of the interests and states of mind of the company and those owing it duties." ${ }^{30}$ However, despite

\footnotetext{
${ }^{25}$ In any event, even if the company in Moore Stephens were suing under the civil law to recover damages imposed by a criminal sentence, the court should carefully consider the different attribution issue that arises from the criminal law as compared to the civil law when it purported to justify the application of the illegality defence on the basis of the consistency rationale.

${ }^{26}[1896] 2 \mathrm{Ch} 743$.

${ }^{27}$ [1979] Ch 250.

${ }^{28}$ [1984] QB 624.

${ }^{29}$ Stone \& Rolls v Moore Stephens [2009] 1 AC 1391 at para 227 per Lord Mance (dissenting).

${ }^{30}$ Stone \& Rolls v Moore Stephens [2009] 1 AC 1391 at para 231 per Lord Mance (dissenting).
} 
Lord Mance's and Lord Scott's vigorous dissent, the majority in Moore Stephens attributed the fraud of the sole director and shareholder to the company and held that the illegality defence precluded the company's claim. Likewise, the court in Safeway attributed the illegal acts of the defendants to the company and struck out the company's claim. ${ }^{31}$

\section{B. Separate Legal Personality}

By barring the company from suing the defendant directors and auditors for breach of duties, the court in Safeway and Moore Stephens was ignoring or bypassing the separate legal personality of the company and treating the directors and employees (in the case of Safeway) and the sole director and shareholder (in the case of Moore Stephens) as though they were the company itself who were seeking to challenge the illegality defence. But the company is a legal persona in its own right. Although it is an artificial entity and can only act through natural persons, it is to be treated as a legal personality separate and distinct from its directors and members. This is a fundamental principle of company law. The separate legal personality of the company in Safeway and Moore Stephens has to be respected because the directors' illegality in those cases constituted a breach of duty that they owed to the company. The separate legal personality has to be recognized because neither Safeway nor Moore Stephens involved a situation in which all of the shareholders in a solvent company concur in committing the company to some decision within its memorandum of association..$^{32}$

\footnotetext{
${ }^{31}$ Safeway Stores Ltd v Twigger [2010] EWCA Civ 1472 at para 29 (per Longmore LJ).

${ }^{32}$ Meridian Global Funds Management Asia Ltd. v Securities Commission [1995] 2 AC 500 at 507 (per Lord Hoffmann); Stone \& Rolls v Moore Stephens [2009] 1 AC 1391 at 1523 (per Lord Mance dissenting).
} 
Where a company seeks compensation for the penalty caused by the directors' wrongdoing by suing a director for breach of duties, the company is not seeking to shift its legal responsibility to the director and seeking to evade consequences of its conduct. On the contrary, to allow the company's claim would only mean holding a director responsible and in doing so, a company is a separate legal personality enforcing duties owed to it by the director. The company in Safeway was invoking the very well-established common law and statutory ${ }^{33}$ remedies that are available to it for breach of directors' duties, which are neither precluded nor supplanted by the Competition Act $1998 .{ }^{34}$ It was not asking the court to act inconsistently with the law as the company and directors are separate legal personalities. The company was merely enforcing, and not seeking to profit from but to obtain compensation for, breach of the duties which the defendants owed to it.

Further, preventing the company from enforcing the breach of duties committed by the directors will produce a startling result: the fraudulent or negligent directors can commit the company to serious illegality ${ }^{35}$ and then escape liability with impunity, however egregious the damage they inflict on the company and however grave the losses that might subsequently be caused to the innocent shareholders during solvency and innocent stakeholders (such as employees, suppliers and especially creditors) during insolvency, if the company were to plead or rely on this illegality to establish its claim. ${ }^{36}$ This is all the more unsatisfactory since any damages that the company in

\footnotetext{
${ }^{33}$ Companies Act 2006, section 178.

${ }^{34}$ P. Watts, "Illegality and Agency Law: Authorising Illegal Action" (2011) J.B.L. 213.

${ }^{35}$ Flaux J in the High Court described the company's conduct, which was caused by the delinquent directors and employees, as "morally reprehensible". Safeway Stores v Twigger [2010] EWHC 11 (Comm) at para 28.

${ }^{36}$ E. Lim, “A Critique of Corporate Attribution: "Directing Mind and Will” and Corporate Objectives” J.B.L. (forthcoming).
} 
Safeway could recover from the directors and employees if its claim were to succeed would not go to them. This is because there was no indication on the facts that the delinquent directors and employees were also the shareholders; and even if they were, contribution proceedings would leave them with no benefit from any damages recovered. Similarly, the delinquent director in Moore Stephens would not benefit from any damages that the company might recover from the auditors because it was insolvent and would have remained so. ${ }^{37}$

\section{CORPORATE OBJECTIVES}

Courts should consider the effect of corporate objectives on whether and to the extent to which the illegality defence should be allowed to defeat a company's claim. ${ }^{38}$ Under the "enlightened shareholder" model, the purpose of the company is to create value for the benefit of shareholders while taking account the interests of the different stakeholders. ${ }^{39}$ Under the "stakeholder theory" of corporate objective, however, a company serves as a vehicle to address the interests of the different stakeholders: shareholders are not the only ones who are most affected by the company's decisions; there are employees, creditors, suppliers and communities who make contributions to the company. ${ }^{40}$

\footnotetext{
${ }^{37}$ Stone \& Rolls v Moore Stephens [2009] 1 AC 1391 at para 121 Lord Scott (dissenting).

${ }^{38}$ E. Lim, "A Critique of Corporate Attribution: "Directing Mind and Will" and Corporate Objectives" J.B.L. (forthcoming).

${ }^{39}$ Rt Hon Lady Justice Arden, "Regulating the Conduct of Directors" (2010) J.C.L.S. 1, 7.

${ }^{40}$ M. Blair and L. Stout, 'Specific Investments and Corporate Law' (2006) 7 European Business Organization Law Review 473.
} 
Ultimately, it is the owners of the company who will bear the adverse consequences when a solvent company performs badly or incurs certain serious liabilities and it is the creditors who will (among other stakeholders) bear the adverse consequences when a company is insolvent. For example, as the company in Safeway was precluded from recovering from the defendants the penalty imposed upon it which could exceed $£ 16$ million, it had to be met out of the company and hence the members' funds. And by barring the company's claim in Moore Stephens, the liquidator was prevented from recovering damages, in an amount that exceeded US\$94 million, for the benefit of the company's creditors (which were the banks defrauded by the delinquent director).

Thus, under the enlightened shareholder model, by barring a solvent company's claim on the basis of the illegality defence, a court fails to protect the shareholders for whose interests the company is run and since directors owe duties to the company for the sake of the shareholders whose interests the company exists to protect and advance, depriving the company its wellestablished right under common law to enforce the duties owed to it by directors is disproportionate to the harmful consequences to be borne by the company and ultimately the shareholders, which harm was caused by the illegal conduct of the directors in the first place, and who in the very first place were under a duty not to commit such illegality and cause harmful consequences. And under the stakeholder theory, barring an insolvent company's claim on the ground of illegality defence is particularly unjust because the interests of the stakeholders (i.e. employees, suppliers and especially creditors) will be critically jeopardized. 
Finally, where a company sues a third party (such as auditors in the case of Moore Stephens), the third party will not necessarily be liable for an indeterminate amount for an indeterminate time to an indeterminate class because the company is only suing to recover for its losses (which are for the benefit of the creditors); the company is not suing to recover any personal losses suffered by any particular stakeholder. ${ }^{41}$ The auditors' duty of care is owed to the company for the benefit of the creditors, and not to the individual creditor or stakeholder.

\section{THE COMPANIES ACT 2006 (THE “ACT")}

Although the prevention of inconsistency, or the pursuit of harmony ${ }^{42}$, between the different aspects or branches of law is a central policy rationale underlying the illegality defence, the case law is not consistent with several provisions in the Act which provide for civil remedies for a company when it is subject to sanctions as a result of its commission of certain criminal offences. These civil remedies are targeted at the directors and others, the purpose of which is to ameliorate the consequences of those criminal sanctions on the company. It is suggested that one reason for this is that although there are justifications as to why the company should be primarily liable if it breaches an obligation under the Act, the breach will also unfairly cause detriment to the company's shareholders (and presumably other stakeholders). Conviction may lead to a fine and which have to be drawn from the company and hence shareholders' funds. The innocent shareholders will be penalized twice, once by the company's failure to comply with its obligations under the Act, the result of which may have already caused serious losses to the shareholders and other stakeholders, and the second time by the fine.

\footnotetext{
${ }^{41}$ Stone \& Rolls v Moore Stephens [2009] 1 AC 1391 at para 269 (per Lord Mance dissenting).

${ }^{42}$ Gray v Thames Trains [2009] 1 AC 1339 at 1384 (per Lord Rodger).
} 
Examples of a civil remedy available to a company include firstly, a company can sue the delinquent directors (for damages for conspiracy, for example) despite being a party to a transaction that infringes the criminal prohibition against financial assistance under section $678 .{ }^{43}$ Secondly, under section 463(2), a company can make a claim against directors for compensation for any loss it suffers as a result of any untrue or misleading statement in the directors' report. Finally, under sections 580(2) and 593(3), a company can make a claim against an allotee of shares in the situation in which it will have a committed a criminal offence ${ }^{44}$ by allotting them to him.

Further, the Act contemplates the possibility of a company having a civil claim against the directors or others that arises from circumstances in which the company has committed an offence under the Act and in which criminal sanction could be imposed on the company. Sections 590, 607 and 680 provide that if a company contravenes the applicable provisions, "an offence is committed by the company and every officer of the company who is in default." The punishment is a fine which can be imposed on the company and/or officer. If an offence is committed by an officer of the company, the officer has arguably breached its duties to the company. Construing sections 590, 607 and 680 together with the common law and statutory ${ }^{45}$ remedies available to a company for breach of director's duties leaves open the possibility of a company having a civil claim against its directors and officers that arise from the circumstances in which criminal sanction has been imposed on the company.

\footnotetext{
${ }^{43}$ Belmont Finance v Williams Furniture [1979] Ch 250 (CA).

${ }^{44}$ Companies Act 2006, sections 590 and 607.

${ }^{45}$ Companies Act 2006, section 178.
} 
Thus, by categorically barring the company's civil claim against the directors and employees for conspiracy, breach of duties and negligence, the reasoning and result in Safeway are inconsistent with the spirit of those provisions in the Act which, firstly, specifically provide for civil remedies for the company against directors and others, and secondly, do not preclude the company from enforcing duties owed to it by directors and officers, despite criminal sanctions being imposed on the company.

Finally, a key policy justification underlying the Act for not imposing criminal sanctions on directors who are in breach of their duties is that it would be inappropriate for public authorities to intrude on the company's decision making process concerning how directors' duties should be enforced as that is a civil domestic matter best left to the discretion of the company. ${ }^{46}$ But if a company is barred from suing directors for breach of duties because of the illegality defence, taking away this decision-making capacity from the company is not only inconsistent with, but it actually undermines, that policy justification. Also, it raises the broader question - which is beyond the scope of this article - as to whether there is a need to revisit the issue concerning whether the Australian mode ${ }^{47}$ (which was rejected by the Company Law Review Steering Group), which imposes criminal sanctions on directors who are in breach, should be adopted. This issue becomes particularly pertinent if a company will be subject to serious harm as a result of the imposition of criminal sanctions and if it cannot recover the damages caused by these

\footnotetext{
${ }^{46}$ Modern Company Law for a Competitive Economy: Completing the Structure, A consultation document from the Company Law Review Steering Group, November 2000, Chapter 13 at para 13.36.

${ }^{47}$ See section 184 of the Corporation Law of Australia.
} 
sanctions from the delinquent directors, and if imposing criminal sanctions on the delinquent directors will achieve the same effect as penalising the company.

\section{CONCLUSION}

This article has argued that courts should carefully bear in mind the distinctive considerations pertaining to company law whenever defendants invoke the illegality defence in order to defeat the claims brought by companies seeking to enforce duties owed to them. Failure to do so will lead to a distorted application of the consistency rationale underlying the illegality defence. Finally, it is important to bear in mind what the Law Commission wrote in its 2009 Report: “... we consider that the illegal defence would succeed in only the most serious of cases. That is, we believe that the policy issues underlying the defence would have to be overwhelming before it would be a proportionate response to deny the claimant his or her usual....rights." ${ }^{48}$

\footnotetext{
${ }^{48}$ The Law Commission (England and Wales), The Illegality Defence: A Consultative Report, Consultation Paper No 189 (2009) at para 3.141, p 62 (emphasis added).
} 